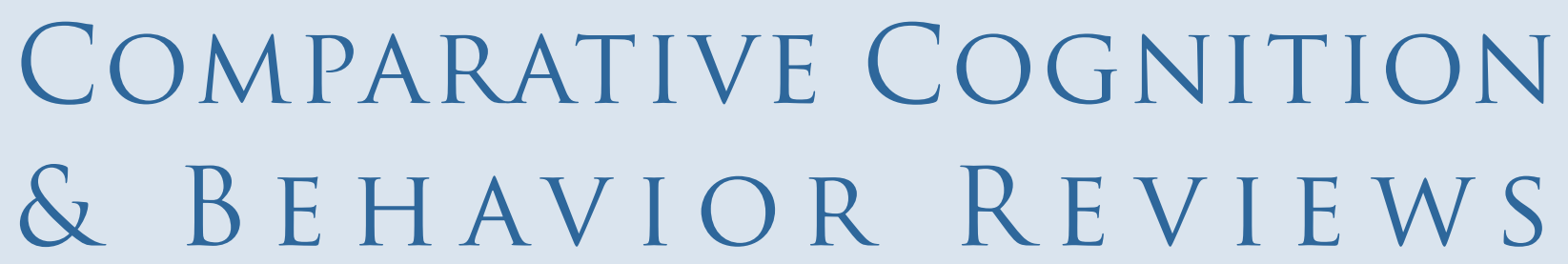

\title{
What Can Nest-Building Birds Teach Us?
}

\author{
Alexis J. Breen, Lauren M. Guillette, and Susan D. Healy \\ School of Biology, University of St Andrews, UK
}

For many years nest building in birds has been considered a remarkable behaviour. Perhaps just as remarkable is the public and scholarly consensus that bird nests are achieved by instinct alone. Here we take the opportunity to review nearly 150 years of observational and experimental data on avian nest building. As a result we find that instinct alone is insufficient to explain the data: birds use information they gather themselves and from other individuals to make nest-building decisions. Importantly, these data confirm that learning plays a significant role in a variety of nest-building decisions. We outline, then, the multiplicity of ways in which learning (e.g., imprinting, associative learning, social learning) might act to affect nest building and how these might help to explain the diversity both of nest-building behaviour and in the resulting structure. As a consequence, we contend that nest building is a much under-investigated behaviour that holds promise both for determining a variety of roles for learning in that behaviour as well as a new model system for examining brain-behaviour relationships.

\section{Keywords: nest building, learning, cognition, comparative cognition, birds}

\section{Introduction}

The notion that learning might be involved in nest building was not lost on inquiring minds in the 19th century, including that of Alfred Russell Wallace (1823-1913). He may have been the first to argue that nest building in birds was not due entirely to instinct: "[t]his point [...] is always assumed without proof, and even against proof, for what facts there are, are opposed to it" (Wallace, 1867). Ironically, despite the passing of nearly 150 years, Wallace's statement is as relevant today with regard to both the popular and scientific opinion as it was in his time. Indeed, at present nest building in birds is a behaviour considered to reflect nothing more than genes (Bluff, Weir, Rutz, Wimpenny, \& Kacelnik, 2007; Hansell \& Ruxton, 2008; Raby \& Clayton, 2009; Seed \& Byrne, 2010; Zentall, 2006). This view, however, continues to be based largely on untested assumptions, as there are very few data on how birds 'know' what type of nest to build.
Helpfully, there are other aspects of birds' nest building that are quite well described. Indeed, several excellent bodies of work provide a broad overview and thorough discussion of this key component of avian reproductive biology (e.g., Collias \& Collias, 1984; Deeming \& Reynolds, 2015; Hansell, 2000). In brief, there are considerable data on the inter- and intraspecific variation in nest-site selection, composition, morphology, and building techniques. This wealth of data reveal an abundance of diversity in all these features of building: (a) birds build nests in an extraordinary range of different sites (Hansell, 2000); (b) where the individual builders of most species are known, nest building is not necessarily restricted to one of the sexes and contribution by one or both partners varies considerably from species to species (Collias \& Collias, 1984; Hansell, 2000); and (c) nest material composition is highly variable, encompassing a broad range of both natural (e.g., grasses, leaves, twigs, sticks, mud, mosses, lichens, feathers, and/or 
arthropod silk) and man-made (e.g., cigarette butts, polypropylene string, and bits of fence wire) materials (Antczak et al., 2010; Hansell, 2000; Nicolakakis \& Lefebvre, 2000; Suárez-Rodríguez, López-Rull, \& Garcia, 2013).

The techniques with which birds build their nests have also been described in some detail and are also various: they range from the sculpting of burrows or cavities from substrate excavation, through the moulding of mud or salivary mucus by vibrating head and/or shaping breast and feet movements, the piling up of materials where subsequent bill manipulations, coupled with side-to-side shaking movements, may be made in order to entangle or intertwine nest components, to the weaving of hanging nest baskets using intricate tuck, looping, interlocking, winding, and knotting bill-made stitches to fasten and secure grassy materials (Collias \& Collias, 1984; Hansell, 2000).

At the most 'basic' level, nest-building efforts may culminate in a seemingly haphazard arrangement of piledup materials, such that a mound or plate (located on or above the ground, respectively) of sticks and twigs provides birds with a nesting substrate, whereas more intricate nests incorporate distinct egg-holding cavities and/or overhead, protective roofing (Hansell, 2000). Lastly, yet most pertinent, nest building is key to (most) birds' reproductive success. Indeed, it has been argued that birds' continued radiation following the end of the Cretaceous period may have been due to the provision of a protected area for egg incubation, enabling those species to buffer their offspring from a rapidly changing environment (Deeming \& Ferguson, 1989).

The building process, then, begins with nest-site selection and is followed by the appropriate choice of available materials from the environment, which individuals then manipulate and/or modify into the structure we call a nest. The builders may subsequently continue to modify that structure even when it contains eggs, chicks, or an incubating parent. For all this variability in all aspects of nest building, a question that has been rarely asked is whether one or more parts of the nest-building process involve decision making. Given that birds have long been models for investigating learning and memory and for examining

\footnotetext{
Author Note: Correspondence concerning this article should be addressed to Alexis J. Breen at ab297@st-andrews. ac.uk, Lauren M. Guilletteatlmg4@st-andrews.ac.uk, and Susan D. Healyatsdh11@st-andrews.ac.uk.

Acknowledgments: We thank the School of Biology at the University of St Andrews for funding (AJB) and the BBSRC (LMG: BB/M013944/1 and SDH: BB/I019634/1). We would also like to thank three anonymous reviewers for providing useful and insightful comments on an earlier version of the manuscript.
}

brain-behaviour relationships, it is curious that such a familiar avian behaviour has been so little explored. It seems timely, then, to review the available data, to examine the interpretations reached from those data, and to suggest directions for future research.

We begin with a historical backdrop to the current view that birds' nest building is entirely innate (Table 1). We next present observational and experimental data collected from both the field and the laboratory to demonstrate that nest building in birds: (a) is not fixed; (b) is experiencedependent; and (c) reflects inter- and intraspecific information use (Tables 2 and 3). In doing so, these data offer belated confirmation of Wallace's belief that, indeed, learning (defined here as a change in an individual's behaviour in response to previous experience with a given, or similar, stimulus; Domjan, 2014) plays a dominant role in birds' nest building. Coupling this evidence with the enormous diversity in the structures produced, we suggest that nest building in birds might provide a useful comparative model behaviour system because its study allows for both the experimental examination of the processes of learning and memory as well as of the underlying neurobiology.

\section{A Brief History}

One form of learning that is well studied in birds is imprinting (Bateson, 1966, 2015). Imprinting is the mechanism whereby an animal acquires a preference for a particular stimulus due to exposure to that stimulus during a sensitive, typically juvenile, phase (Bateson, 1966). The possibility that young birds may learn what nest they are to build as adults through imprinting on some feature(s) of their natal nest experience was the impetus behind a series of early experiments (Table 1, Section 1) addressed at determining whether the nest a bird builds as an adult bears any relationship to that from which they fledged (Sargent, 1965). Sargent manipulated three distinct features of the young birds' natal nest: (a) the colour of the nest material he provided (brown, green, or red); (b) the form of the structure in which the birds could build (an enclosed or open nest-cup); and (c) the location of the nestbox/cup (inside the cage or in a cage extension). Sargent reared zebra finches Taeniopygia guttata in an experimental design with these three components cross-factored and, when the males (they are the builder in this species) built their first nest, Sargent tested their preferences for material colour, structure, and location. Natal nest colour did not appear to influence adult colour preference as all the males strongly preferred to build with brown nest material, regardless of the colour of the nest in which they had been reared. Similarly, natal nest 
Table 1. Early observational and experimental studies that demonstrate that birds' nest-building behaviour is not fixed and is experience-dependent.

$\begin{array}{llll}\text { Species } & \text { Author } & \text { Methods } & \text { Conclusion }\end{array}$

Learning in nest-building birds: Historical evidence

1) Early-life experience affects birds' nest building

\begin{tabular}{|c|c|c|c|}
\hline $\begin{array}{l}\text { Zebra finch } \\
\text { (Taeniopygia guttata) }\end{array}$ & Sargent (1965) & $\begin{array}{l}\text { Males' nest pref- } \\
\text { erences tested } \\
\text { between (a) natal \& } \\
\text { first nest and (b) first } \\
\& \text { second nests built }\end{array}$ & $\begin{array}{l}\text { Natal nest habi- } \\
\text { tat influenced first- } \\
\text { time builders' deci- } \\
\text { sions, but colour } \\
\text { \& substrate did } \\
\text { not; habitat effect } \\
\text { decreased between } \\
\text { first \& second nests }\end{array}$ \\
\hline
\end{tabular}

American robin
(Turdus migratorius)

(Turdus migratorius)

Rose-breasted grosbeak

(Pheucticus

ludovicianus)

\begin{abstract}
For 2 years pairs provided with mud, grasses, and rootlets; in 3rd year also provided a circular nest basket

For 2 weeks pair provided with nest materials; in 3rd week also provided an artificial nest
\end{abstract}

Birds reared in artifi-
Domesticated canary (Serinus canaria domestica) cial containers

Veraline (1934)
Hinde (1958)

$\begin{array}{ll}\text { Village weaverbird } & \text { Collias \& Collias } \\ \text { (Ploceus cucullatus) } & (1964)\end{array}$

\begin{abstract}
Males reared in complete or partial absence (30 $\mathrm{min} /$ day exposure) of nest material tested for nest building ability as adult
\end{abstract}

Males reared in absence of nest material tested for material colour, length and rigidity preferences; tested as adult
First 2 years females did not build normal nest; 3rd year they built in nest basket provided

First 2 weeks birds began and then aborted building repeatedly; 3rd week added nest lining to, and laid in, artificial nest provided

Birds reared in artificial containers did not build nests that resembled those built by birds reared in normal nests

Males exhibited abnormal building behaviours as adults (e.g., carrying material in and out of nestbox or plucking and building with own feathers)

Males exhibited normal material preferences but less capable at weaving than non-deprived birds, deprived birds' weaving skills improved over time

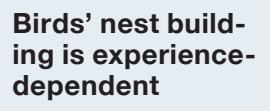

Birds' nest building is experiencedependent

Birds' nest building is not fixed

\section{Birds' nest building \\ is not fixed}

\section{Birds' nest building is not fixed}

\section{Birds' nest building is not fixed}

Birds' nest building

is not fixed
Imprinting

Motor learning

Motor learning

Motor learning

Motor learning

Motor learning

2) Birds' nest-site selection is plastic

\begin{tabular}{llll|l}
\hline $\begin{array}{l}\text { Yellow wagtail } \\
\text { (Motacilla flava) }\end{array}$ & Schiermann (1939) & $\begin{array}{l}\text { Observed females' } \\
\text { choice of nesting } \\
\text { location }\end{array}$ & $\begin{array}{l}\text { Subgroups of } \\
\text { females found to } \\
\text { nest not on the } \\
\text { ground (typical), } \\
\text { but above ground } \\
\text { (atypical) }\end{array}$ & $\begin{array}{l}\text { Birds' nest building } \\
\text { is not fixed }\end{array}$ \\
\hline $\begin{array}{l}\text { Redhead } \\
\text { (Aythya americana) }\end{array}$ & Hochbaum (1955) & $\begin{array}{l}\text { Observed females' } \\
\text { choice of nesting } \\
\text { location }\end{array}$ & $\begin{array}{l}\text { Subgroups of } \\
\text { females found to } \\
\text { nest not over water } \\
\text { (typical), but on land } \\
\text { (atypical) }\end{array}$ & $\begin{array}{l}\text { Birds' nest building } \\
\text { is not fixed }\end{array}$ \\
\hline
\end{tabular}


Table 2. Observational and experimental studies conducted in the field since the start of the 20th century that provide evidence that birds' nest-building behaviour is not fixed, is experience-dependent, and reflects inter- and intraspecific information use.

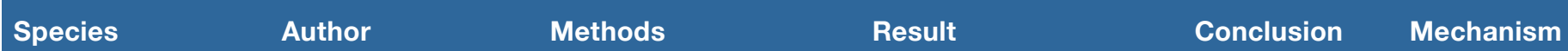

Learning in nest-building birds: Evidence from the field

1) Nest morphology and/or building techniques are not necessarily repeatable

Southern masked Walsh et al. (2010) Measured length, width,

weaverbird

(Ploceus velatus)

Walsh et al. (2011)

Walsh et al. (2013)

Bailey et al. (2015)

Village weaverbird

(Ploceus cucullatus)

Walsh et al. (2010)

Performed image texture analysis on multiple nests built by the same males in one season

Measured length, width, and height of multiple nests built by the same males in one season

Bailey et al. (2015)

Performed image texture analysis on multiple nests built by the same males in one season
Structural dimensions showed low, but significan repeatability across nests built by the same males

The majority of nest-building behaviours were not repeatable within males; building behaviours within males changed over multiple nests

Males do not complete a nest before beginning a new one; building behaviours do not reflect the use of feedback loops (stigmergy) or fixed-action patterns (stereotypy)

Textural variation in nests can be correctly identified on an individual level up to $81.82 \%$

Structural dimensions showed low and nonsignificant repeatability across nests built by the same males

Textural variation in nests can be correctly identified on an individual level up to $81.82 \%$

\begin{tabular}{l|l|}
$\begin{array}{l}\text { Birds' nest } \\
\text { building is not } \\
\text { fixed }\end{array}$ \\
\hline $\begin{array}{l}\text { Birds' nest } \\
\text { building is not } \\
\text { fixed }\end{array}$ \\
\hline $\begin{array}{l}\text { Birds' nest } \\
\text { building is not } \\
\text { fixed }\end{array}$ \\
\hline $\begin{array}{l}\text { Birds' nest } \\
\text { building is not } \\
\text { fixed }\end{array}$ \\
\hline $\begin{array}{l}\text { Birds' nest } \\
\text { building is not } \\
\text { fixed }\end{array}$ \\
\hline fixed
\end{tabular}

2) Reproductive success affects birds' nest-site selection

Collared flycatcher

(Ficedula albicollis)

Doligez et al. (1999)

\section{Analysed demographic} (nest location) and behavioural (breeding success or failure) data collected over 14 yr period

\section{Goldeneye}

(Bucephala clangula)

Dow \& Fredga (1983)

Analysed demographic (nest location) and behavioural (breeding success or failure) data collected over $17 \mathrm{yr}$ period

Northern flicker (Colaptes auratus)
Fisher \& Wiebe (2006) Analysed demographic (nest location) and behavioural (breeding success or failure) data collected over $7 \mathrm{yr}$ period
Between-year breedingsite fidelity varied: unsuccessful birds more likely to change the location of their nests

Between-year breeding-site fidelity varied: unsuccessful birds more likely to change the location of their nests and to move further than successful birds

Between- and withinyear breeding-site fidelity varied: unsuccessful birds more likely to change the location of their nest within and between breeding seasons

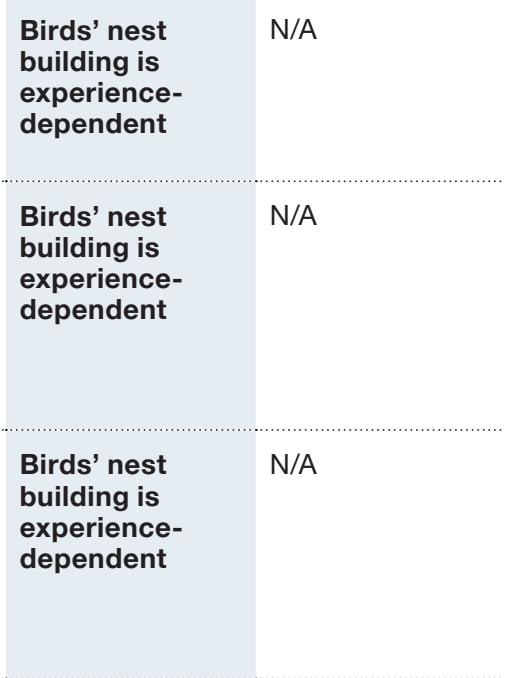




\begin{tabular}{|c|c|c|c|c|c|}
\hline Species & Author & Methods & Result & Conclusion & Mechanism \\
\hline $\begin{array}{l}\text { Stonechat } \\
\text { (Saxicola rubicola) }\end{array}$ & Greg-Smith (1982) & $\begin{array}{l}\text { Analysed demographic } \\
\text { (nest location) and behav- } \\
\text { ioural (breeding success or } \\
\text { failure) data collected over } \\
3 \text { yr period }\end{array}$ & $\begin{array}{l}\text { Within-season breeding- } \\
\text { site fidelity varied: unsuc- } \\
\text { cessful birds more likely to } \\
\text { move further, and change } \\
\text { nest cover type, than } \\
\text { successful birds }\end{array}$ & $\begin{array}{l}\text { Birds' nest } \\
\text { building is } \\
\text { experience- } \\
\text { dependent }\end{array}$ & $\mathrm{N} / \mathrm{A}$ \\
\hline $\begin{array}{l}\text { Orange-breasted } \\
\text { sunbird } \\
\text { (Anthobaphes } \\
\text { violacea) }\end{array}$ & $\begin{array}{l}\text { Grégoire \& Cherry } \\
\text { (1982) }\end{array}$ & $\begin{array}{l}\text { Manipulated outcome } \\
\text { of birds' breeding } \\
\text { attempt (success or fail- } \\
\text { ure); measured dispersal } \\
\text { distance between each } \\
\text { attempt }\end{array}$ & $\begin{array}{l}\text { Breeding dispersal } \\
\text { distances between subse- } \\
\text { quent nesting attempts for } \\
\text { unsuccessful birds (nests } \\
\text { predated) were twice those } \\
\text { of successful birds }\end{array}$ & $\begin{array}{l}\text { Birds' nest } \\
\text { building is } \\
\text { experience- } \\
\text { dependent }\end{array}$ & $\begin{array}{l}\text { Associative } \\
\text { learning }\end{array}$ \\
\hline $\begin{array}{l}\text { American robin } \\
\text { (Turdus migratorius) }\end{array}$ & Haas (1998) & $\begin{array}{l}\text { Manipulated outcome } \\
\text { of birds' breeding } \\
\text { attempt (success or fail- } \\
\text { ure); measured dispersal } \\
\text { distance between each } \\
\text { attempt }\end{array}$ & $\begin{array}{l}\text { Birds that successfully } \\
\text { reared chicks (vs. unsuc- } \\
\text { cessful) more likely to } \\
\text { return to nest in the same } \\
\text { area the following year }\end{array}$ & $\begin{array}{l}\text { Birds' nest } \\
\text { building is } \\
\text { experience- } \\
\text { dependent }\end{array}$ & $\begin{array}{l}\text { Associative } \\
\text { learning }\end{array}$ \\
\hline $\begin{array}{l}\text { Brown thrasher } \\
\text { (Taxostoma rufum) }\end{array}$ & Haas (1998) & $\begin{array}{l}\text { Manipulated outcome } \\
\text { of birds' breeding } \\
\text { attempt (success or fail- } \\
\text { ure); measured dispersal } \\
\text { distance between each } \\
\text { attempt }\end{array}$ & $\begin{array}{l}\text { Birds that successfully } \\
\text { reared chicks (vs. unsuc- } \\
\text { cessful) more likely to } \\
\text { return to nest in the same } \\
\text { area the following year }\end{array}$ & $\begin{array}{l}\text { Birds' nest } \\
\text { building is } \\
\text { experience- } \\
\text { dependent }\end{array}$ & $\begin{array}{l}\text { Associative } \\
\text { learning }\end{array}$ \\
\hline $\begin{array}{l}\text { Mountain bluebird } \\
\text { (Sialia currucoides) }\end{array}$ & Herlugson (1981) & $\begin{array}{l}\text { Analysed demographic } \\
\text { (nest location) and behav- } \\
\text { ioural (breeding success or } \\
\text { failure) data collected over } \\
2 \text { yr period }\end{array}$ & $\begin{array}{l}\text { Between-season breed- } \\
\text { ing-site fidelity varied: } \\
\text { successful breeders more } \\
\text { likely to select the same } \\
\text { nestbox type than unsuc- } \\
\text { cessful birds }\end{array}$ & $\begin{array}{l}\text { Birds' nest } \\
\text { building is } \\
\text { experience- } \\
\text { dependent }\end{array}$ & N/A \\
\hline \multirow[t]{2}{*}{$\begin{array}{l}\text { Black-legged } \\
\text { kittiwake } \\
\text { (Rissa tridactyla) }\end{array}$} & Danchin et al. (1998) & $\begin{array}{l}\text { Analysed demographic } \\
\text { (nest location) and behav- } \\
\text { ioural (breeding success or } \\
\text { failure) data collected over } \\
22 \text { yr period }\end{array}$ & $\begin{array}{l}\text { Birds that nested in high- } \\
\text { predation areas less likely } \\
\text { to return following breed- } \\
\text { ing failure }\end{array}$ & $\begin{array}{l}\text { Birds' nest } \\
\text { building is } \\
\text { experience- } \\
\text { dependent }\end{array}$ & $\mathrm{N} / \mathrm{A}$ \\
\hline & Suryan \& Irons (2015) & $\begin{array}{l}\text { Analysed demographic } \\
\text { (nest location) and behav- } \\
\text { ioural (breeding success or } \\
\text { failure) data collected over } \\
12 \text { yr period }\end{array}$ & $\begin{array}{l}\text { Birds that nested in high- } \\
\text { predation areas less likely } \\
\text { to return following breed- } \\
\text { ing failure }\end{array}$ & $\begin{array}{l}\text { Birds' nest } \\
\text { building is } \\
\text { experience- } \\
\text { dependent }\end{array}$ & $\mathrm{N} / \mathrm{A}$ \\
\hline $\begin{array}{l}\text { Spotted antbird } \\
\text { (Hylophylax } \\
\text { naevioides) }\end{array}$ & Styrsky (2005) & $\begin{array}{l}\text { Analysed demographic } \\
\text { (nest location) and behav- } \\
\text { ioural (breeding success or } \\
\text { failure) data collected over } \\
2 \text { yr period }\end{array}$ & $\begin{array}{l}\text { Between- and within-year } \\
\text { breeding-site fidelity } \\
\text { varied: successful birds } \\
\text { more likely to reuse a nest } \\
\text { structure than unsuccess- } \\
\text { ful birds both within and } \\
\text { between breeding seasons }\end{array}$ & $\begin{array}{l}\text { Birds' nest } \\
\text { building is } \\
\text { experience- } \\
\text { dependent }\end{array}$ & $\mathrm{N} / \mathrm{A}$ \\
\hline
\end{tabular}

\section{3) Perceived predation risk affects birds' nest-site selection}

Red-backed shrike Roos \& Pärt (2004) (Lanius collurio)
Analysed demographic (nest location) and behavioural (breeding success or failure) data collected over 3 yr period for focal spp. and predator spp.
Between-year breedingsite fidelity changed in bution of nest predators dependent
N/A

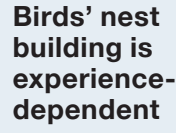

(continues) 
Table 2 (continued). Observational and experimental studies conducted in the field since the start of the 20th century that provide evidence that birds' nest-building behaviour is not fixed, is experience-dependent, and reflects inter- and intraspecific information use.

\begin{tabular}{lll} 
Species & Author & Methods \\
\hline $\begin{array}{l}\text { Ovenbird } \\
\text { (Seiurus } \\
\text { aurocapilla) }\end{array}$ & Morton (2005) & $\begin{array}{l}\text { Analysed demographic } \\
\text { (nest location) and behav- } \\
\text { ioural (breeding success } \\
\text { or failure) data collected } \\
\text { over } 33 \text { yr period for focal } \\
\text { sp. and predator sp. } \\
\text { (chipmunk) }\end{array}$ \\
& &
\end{tabular}

Siberian jay $\quad$ Eggers (2006)

(Perisoreus infaustus)

Exposed nesting birds to nest-predator playbacks in 3 separate years

Black redstart $\quad$ Chen et al. (2011)
(Phoenicurus
ochruros)

Exposed nesting birds to predation threat) in 3 sepa-

Marzluff (1988)

Pinyon jay

(Gymnorhinus

cyanocephalus)

$\begin{array}{ll}\text { Tengmalm's owl } & \text { Hakkarainen et al. } \\ \text { (Aegolius funereus) } & \text { (2001) }\end{array}$

Prothonotary warbler
(Protonotaria citrea)

Peluc et al. (2008)

\section{Result}

Between-year breedingsite fidelity influenced by the distribution of nest predators

Between-year breedingsite fidelity varied: birds exposed to nest-predator playbacks moved twice the distance of the previous year and switched to denser (lower) vegetation human disturbance (highrate years

Analysed demographic (nest location) and behavioural (breeding success or failure) data collected over $5 \mathrm{yr}$ period
Manipulated predation risk (by exposure to a live American mink; Neovision neovision) of some birds' breeding attempts
Between-year breedingsite fidelity varied: birds exposed to high-predation threat levels from humans more likely to move their nests than non-exposed birds

\section{Birds discriminate} between and act selectively towards nest-failure sources: predation failure in exposed site $=$ moved to covered site; environmental failure in covered site $=$ moved to exposed site

Between-year breedingsite fidelity varied: breeding dispersal distance for birds exposed to a simulated predation threat were 3 that of non-exposed birds

Nest-site selection varied: all birds exposed to highpredation environment nested on the ground, whereas the non-exposed birds did not

\section{Conclusion Mechanism}

Birds' nest building is experiencedependent

N/A

\section{Birds' nest building is experience- \\ dependent}

Associative learning

\section{Birds' nest} building is experiencedependent
Exposed nest-site prospecting birds to nest predator taxidermy models and corresponding playbacks

(n)

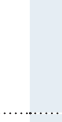

\section{Birds' nest \\ building is \\ experience- \\ dependent}

\section{Birds' nest} building is experiencedependent

\section{Birds' nest} building is dependent experience-
Associative learning

\section{$\mathrm{N} / \mathrm{A}$}

Associative learning

Associative learning

\section{4) Perceived predation risk may affect birds' nest structure}

House wren

(Troglodytes aedon)

Stanbeck et al. (2013)

nestboxentrance hole diameter (large vs. small) where birds built nests

Rock wren

(Salpinctes obsoletus)

Warning \& Benedict (2015)
Measured stone quantity in relation to nest cavity size; tested acoustic properties of each nest cavity
Males built a larger barrier (a pile of sticks) between the nest entrance and nest cup in nests with large, but not small, entrance holes

Birds used more stones in a nest cavity with a large (versus small) entrance; stone presence influenced nest cavity acoustics

\author{
Birds' nest \\ building is not \\ fixed
}

Birds' nest N/A building is not fixed

\section{N/A}

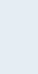




\begin{tabular}{|c|c|c|c|c|c|}
\hline Species & Author & Methods & Result & Conclusion & Mechanism \\
\hline $\begin{array}{l}\text { Black lark } \\
\text { (Melanocorypha } \\
\text { yeltoniensis) }\end{array}$ & Fijen et al. (2015) & $\begin{array}{l}\text { Manipulated dung quantity } \\
\text { (absent or present) for arti- } \\
\text { ficial nests in } 6 \text { experimen- } \\
\text { tal plots; exposed to graz- } \\
\text { ing cows }\end{array}$ & $\begin{array}{l}\text { Artificial nests surrounded } \\
\text { by dung less likely to be } \\
\text { trampled by cows than } \\
\text { those where dung was not } \\
\text { present }\end{array}$ & $\begin{array}{l}\text { Birds' nest } \\
\text { building is not } \\
\text { fixed }\end{array}$ & $\mathrm{N} / \mathrm{A}$ \\
\hline \multicolumn{6}{|c|}{ 5) Local reproductive success affects birds' nest-site selection } \\
\hline $\begin{array}{l}\text { Black-legged } \\
\text { kittiwake } \\
\text { (Rissa tridactyla) }\end{array}$ & Boulinier et al. (2008) & $\begin{array}{l}\text { Reproductive success } \\
\text { manipulated so that certain } \\
\text { nesting areas were 'better' } \\
\text { than others }\end{array}$ & $\begin{array}{l}\text { Birds nested in new loca- } \\
\text { tion the following year if } \\
\text { they and their neighbours } \\
\text { experienced predation, } \\
\text { but did not change loca- } \\
\text { tion if they but not their } \\
\text { neighbours experienced } \\
\text { predation }\end{array}$ & $\begin{array}{l}\text { Birds' nest } \\
\text { building is } \\
\text { experience- } \\
\text { dependent }\end{array}$ & Social learning \\
\hline $\begin{array}{l}\text { Prothonotary warbler } \\
\text { (Protonotaria citrea) }\end{array}$ & Hoover (2003) & $\begin{array}{l}\text { Manipulated outcome } \\
\text { of birds' breeding } \\
\text { attempt (success or fail- } \\
\text { ure); measured dispersal } \\
\text { distance between each } \\
\text { attempt }\end{array}$ & $\begin{array}{l}\text { Between-year breed- } \\
\text { ing-site fidelity varied: } \\
\text { successful birds more } \\
\text { likely to return to the same } \\
\text { area than unsuccessful } \\
\text { birds }\end{array}$ & $\begin{array}{l}\text { Birds' nest } \\
\text { building is } \\
\text { experience- } \\
\text { dependent }\end{array}$ & $\begin{array}{l}\text { Associative } \\
\text { learning }\end{array}$ \\
\hline $\begin{array}{l}\text { Piping plover } \\
\text { (Charadrius melodus } \\
\text { melodus) }\end{array}$ & Rioux et al. (2011) & $\begin{array}{l}\text { Analysed demographic } \\
\text { (nest location) and behav- } \\
\text { ioural (breeding success or } \\
\text { failure) data collected over } \\
8 \text { yr period }\end{array}$ & $\begin{array}{l}\text { Birds nested in new loca- } \\
\text { tion the following year if } \\
\text { they and their neighbours } \\
\text { experienced predation, } \\
\text { but did not change loca- } \\
\text { tion if they but not their } \\
\text { neighbours experienced } \\
\text { predation }\end{array}$ & $\begin{array}{l}\text { Birds' nest } \\
\text { building is } \\
\text { experience- } \\
\text { dependent }\end{array}$ & $\mathrm{N} / \mathrm{A}$ \\
\hline
\end{tabular}

6) Birds use interspecific information to select a nest site

Flycatcher

(Ficedula spp.)

Seppänen \& Forsman
(2007)

Tits' nestboxes manipulated so that all boxes have same arbitrary symbol; tested flycatchers' nestbox choice

Seppänen et al. (2011) Number of eggs/chicks of resident tits counted when migratory flycatchers made nestbox choice

7) Birds actively reject the nestbox choice of poorly performing heterospecifics

Flycatcher (Ficedula spp.)
Loukola et al. (2012)

Number of eggs of simulated resident tits manipulated (low or high) when migratory flycatchers made nestbox choice

Loukola et al. (2014)
Number of eggs of resident tits manipulated (low or high) when migratory flycatchers made nestbox choice
Flycatchers nested in boxes that matched the box-types of resident tits

Flycatchers more likely to copy nestbox choice as number of eggs/chicks increased in resident tits
Birds' nest building involves interspecific information use

Birds' nest building involves interspecific information use
Flycatchers actively avoid the nestbox choices of resident tits with low simulated clutch sizes and copy those with high simulated clutch sizes

Flycatchers actively avoid the nestbox choices of resident tits with low clutch sizes and copy those with high clutch sizes
Birds' nest building involves interspecific information use

Birds' nest building involves interspecific information use
Mechanism
N/A
Social learning
Associative
learning

high clutch sizes

Social learning, Counting, Associative learning

Social learning, Counting, Associative learning

(continues) 
Table 2 (continued). Observational and experimental studies conducted in the field since the start of the 20th century that provide evidence that birds' nest-building behaviour is not fixed, is experience-dependent, and reflects inter- and intraspecific information use.

\begin{tabular}{|c|c|c|c|c|c|}
\hline Species & Author & Methods & Result & Conclusion & Mechanism \\
\hline $\begin{array}{l}\text { Baltimore oriole } \\
\text { (Icterus galbula) }\end{array}$ & Williams (1934) & $\begin{array}{l}\text { Provided pairs natu- } \\
\text { ral (plant) and unnatural } \\
\text { (coloured yarn) materials } \\
\text { over } 10 \text { yr period }\end{array}$ & $\begin{array}{l}\text { Birds increasingly included } \\
\text { unnatural material into } \\
\text { nests; convergence of } \\
\text { colour preference }\end{array}$ & $\begin{array}{l}\text { Birds' nest } \\
\text { building is not } \\
\text { fixed }\end{array}$ & $\mathrm{N} / \mathrm{A}$ \\
\hline $\begin{array}{l}\text { Kingbird } \\
\text { (Tyrannus spp.) }\end{array}$ & Williams (1934) & $\begin{array}{l}\text { Provided pairs natu- } \\
\text { ral (plant) and unnatural } \\
\text { (coloured yarn) materials } \\
\text { over } 10 \text { yr period }\end{array}$ & $\begin{array}{l}5 \text { years after orioles first } \\
\text { did so (see above), females } \\
\text { began to include unnatural } \\
\text { material into nests }\end{array}$ & $\begin{array}{l}\text { Birds' nest } \\
\text { building is not } \\
\text { fixed }\end{array}$ & $N / A$ \\
\hline $\begin{array}{l}\text { American robin } \\
\text { (Turdus migratorius) }\end{array}$ & Williams (1934) & $\begin{array}{l}\text { Provided pairs natu- } \\
\text { ral (plant) and unnatural } \\
\text { (coloured yarn) materials } \\
\text { over } 10 \text { yr period }\end{array}$ & $\begin{array}{l}8 \text { yrs after orioles first did } \\
\text { so (see two above), and } \\
3 \text { yrs after kingbirds (see } \\
\text { above), females included } \\
\text { unnatural material into } \\
\text { nests }\end{array}$ & $\begin{array}{l}\text { Birds' nest } \\
\text { building is not } \\
\text { fixed }\end{array}$ & $N / A$ \\
\hline $\begin{array}{l}\text { Cedar waxwing } \\
\text { (Bombycilla } \\
\text { cedrorum) }\end{array}$ & Williams (1934) & $\begin{array}{l}\text { Provided pairs natu- } \\
\text { ral (plant) and unnatural } \\
\text { (coloured yarn) materials } \\
\text { over } 10 \text { yr period }\end{array}$ & $\begin{array}{l}8 \text { yrs after orioles first did } \\
\text { so (see three above), and } \\
3 \text { yrs after kingbirds (see } \\
\text { two above), birds included } \\
\text { unnatural material into } \\
\text { nests }\end{array}$ & $\begin{array}{l}\text { Birds' nest } \\
\text { building is not } \\
\text { fixed }\end{array}$ & $\mathrm{N} / \mathrm{A}$ \\
\hline $\begin{array}{l}\text { Blue tit } \\
\text { (Cyanistes caeruleus) }\end{array}$ & Mennerat et al. (2009) & $\begin{array}{l}\text { Analysed plant composi- } \\
\text { tion of multiple nests built } \\
\text { by the same females in two } \\
\text { distinct study plots across } \\
3 \text { yr period }\end{array}$ & $\begin{array}{l}\text { Between-year nest compo- } \\
\text { sition consistent within } \\
\text { females but different } \\
\text { across the two plots }\end{array}$ & $\begin{array}{l}\text { Birds' nest } \\
\text { building is not } \\
\text { fixed }\end{array}$ & $N / A$ \\
\hline
\end{tabular}

experience did not appear to affect preference for the kind of structure in which to build: all males chose to build their nests in open nest-cups. Some evidence of imprinting on the natal nest, however, came from the males' preference for building their nest in the location that matched the one in which they were reared. Taken together, Sargent concluded that innate predispositions played the much larger role in his birds' nest-building decision making. To our knowledge, this study is the only one in which the role of imprinting in birds' nest building has been investigated to any significant extent.

We find a few more data on the effect of early-life experience from a handful of deprivation experiments (Table 1 , Section 1) where the typical method has been to deny juvenile birds access to building materials until the birds are sexually mature. These inexperienced adults are then presented with appropriate material (and a mate if required) in order to determine (a) whether the bird(s) can build a nest at all and, if yes, (b) the form the nest takes.

Such deprivation experiments show that a lack of early experience with nest-building material appears to vary in its effect on subsequent nest-building efforts, depending on the species tested (Table 1, Section 1). Hand-reared American robins Turdus migratorius, for example, could not construct a robust nest, even after repeated attempts, although they could line the inside of a nest-cup successfully when provided with such a cup (Scott, 1902). Similarly, a pair of hand-raised rose-breasted grosbeaks Pheucticus ludovicianus failed to construct a nest but they could line an artificial container when one was provided (Scott, 1904). In contrast, domesticated canaries Serinus canaria domestica could construct a complete nest even when deprived entirely of appropriate nest materials when young (Hinde \& Warren, 1959; Verlaine, 1934). It may be that these canary data are a major source for the opinion that nest building is essentially 'hardwired'. Even with the experience-deprived canaries' apparent success, however, behaviours observed during their nest building were described as atypical and the resultant nests appeared 'poorer' in quality (Verlaine, 1934).

That experience is important to first-time nest builders is a view supported by detailed observations on the ontogeny of building behaviour in aviary-housed village weaverbirds Ploceus cucullatus. These birds benefitted from practicing 
Table 3. Observational and experimental studies conducted in the laboratory since the start of the 20th century that provide evidence that birds' nestbuilding behaviour is not fixed and is experience-dependent.

\begin{tabular}{|c|c|c|c|c|c|}
\hline Species & Author & Methods & Result & Conclusion & Mechanism \\
\hline \multicolumn{6}{|c|}{ Learning in nest-building birds: Evidence from the laboratory } \\
\hline \multicolumn{6}{|c|}{ 1) Reproductive success affects birds' material choice } \\
\hline $\begin{array}{l}\text { Zebra finch } \\
\text { (Taeniopygia guttata) }\end{array}$ & Muth \& Healy (2011) & $\begin{array}{l}\text { Males built nest } \\
\text { with un-preferred } \\
\text { colour material; nest } \\
\text { success manipu- } \\
\text { lated; males retested } \\
\text { for colour preference }\end{array}$ & $\begin{array}{l}\text { Males' nest-material- } \\
\text { colour preference } \\
\text { changed if success- } \\
\text { fully raised chicks in } \\
\text { nest built with non- } \\
\text { preferred colour } \\
\text { material }\end{array}$ & $\begin{array}{l}\text { Birds' nest build- } \\
\text { ing is experience- } \\
\text { dependent }\end{array}$ & Associative learning \\
\hline
\end{tabular}

\section{2) Birds' material choice is selective}

Zebra finch
(Taeniopygia guttata)

(Taeniopygia guttata)

\section{Males reared in} nests of a colour that was preferred, or not preferred by father, tested for nest-material colour as adult

Muth \& Healy (2014)

Males given 2 different lengths of nestmaterial, only one of which easily fit into a novel nestbox entrance
Bailey et al. (2014)

\author{
Males given several \\ experiences build- \\ ing with material that \\ differed in rigidity \\ and given multiple \\ preference tests
}

Males do not build nests that match the colour, or morphological characteristics of the nest in which they were reared

Males initially select material that easily fits into nestbox entrance, then change handling technique by trialand-error learning to manipulate remaining material

\section{All males preferred} stiffer nest material (versus flexible) after building experience

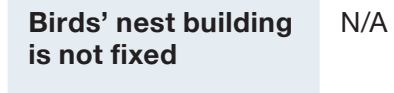

Birds' nest building is not fixed

Trial-and-error learning, Motor learning

Birds' nest building is experience-

Associative learning their motor skills through direct manipulation and/or handling of nest material (Collias \& Collias, 1964; Table 1, Section 1): when provided with access to nest material, juvenile weaverbirds improved at collecting material from plants (e.g., where to tear the leaf, in what direction, and how to perch in order to do so), and they become more proficient at building (by increasing the number of pieces woven within a $3.5 \mathrm{~h}$ observation period by $26 \%$ ). The nests of these first-time builders, however, were characterised as 'crude' in comparison to those built by experienced adults. It appears that motor learning then, at least for weaverbirds, is important to nest building.

Collectively, these early data on nest-building behaviour are, however, sparse and suggestive at most: they do not confirm that learning plays a dominant role in nest building by birds but nor do they confirm its irrelevance. The key problem is that there are so very few data. In the meantime, investigations of building behaviour have focussed largely on the invertebrates, work that has lead to the general conclusion that relatively simple rules can be sufficient to explain even apparently complex structures (Hansell, 1984). Building by invertebrates has, unsurprisingly, lead to the assumption that building by birds might have a similar mechanistic basis, and may explain why Wallace's view has received so little attention. Those invertebrate data may also help to explain why there has been little attempt to determine how a bird 'knows' what nest to build: we thought we knew. Recent data from both the field and laboratory on a number of components of bird nest building, however, show that we don't actually know what we think we do: learning does play a role in nest building. 


\section{Learning in Nest-Building Birds: Evidence from the Field}

\section{Measuring Heritability}

Virtually all behaviour reflects an interaction between genetic endowment, ontogenetic processes, and later experience-dependence. One way to assess the extent to which genes and experience may or may not influence birds' nest-building behaviours is to measure the repeatability of those behaviours over time (i.e., the upper limit of heritability; Boake, 1989; Lessells \& Boag, 1987). As solitary weaverbirds build multiple nests over the course of a single breeding season, they provide an opportunity to examine repeatability in the gross morphology (length, width, height) of their nests. If male weaverbirds build nests using a genetic 'template' one would expect high inter-male repeatability $(\mathrm{R})$ with regard to nest dimensions. Examination of 93 nests build by 20 individual males (e.g., southern masked Ploceus velatus and village weaverbirds $P$. cucullatus; $\sim 4$ nests/male) showed this was not the case (southern masked weavers: $R=0.21$; village weavers: $R=0.07$; Walsh, Hansell, Borello, \& Healy, 2010; Table 2, Section 1). Moreover, the repeatability of building actions (such as carrying, inserting, and dropping grass) the birds performed during two key phases (initial attachment and ring phase; Figure 1) was variable: in the initial attachment phase none of the measured behaviours were repeatable, whereas in the ring phase, three out of the five behaviours were (Walsh, Hansell, Borello, \& Healy, 2011).
That simple rule-based explanations did not necessarily account for the constituent behaviours used by southern masked weavers when building their nests was confirmed by examination of the movements the birds made when building sequential nests (Walsh, Hansell, Borello, \& Healy, 2013; Table 2, Section 1). If the birds used either of two possible rules to build a nest: (a) stigmergy (i.e., using predetermined stimulus-response reactions) or (b) stereotypy (i.e., using a set sequence of repetitive actions), one would expect to see a sequential and nonoverlapping progression of discrete, discriminable building phases. Additionally, both of these rule-based behaviours should result in birds completing a nest before beginning the construction of a new one. But the birds did not do this. Rather there was no discernible pattern to the order in which building weavers visited their nests to tidy or to add new material.

A pattern in individual weaverbird nest building, however, has been detected using computer-aided image texture classification (Bailey et al., 2015; Table 2, Section 1): from examination of textural surface patterns, the identity of the builder of 96 village and southern masked weaverbird nests could be identified with varying (up to $81.82 \%$ ) accuracy ( $\sim 5$ nests/male). As it appears that there is some compositional consistency or 'signature' to the final nest structure built by each weaverbird (such as can be assigned to pieces painted by individual artists), it is possible that weaverbirds develop their own 'style' of building, which then becomes fixed. If this is the case, then nest building might bear a

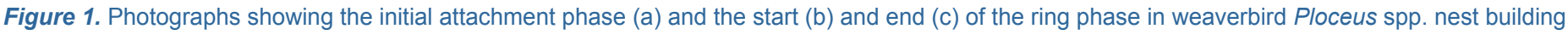

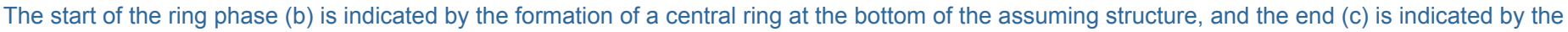

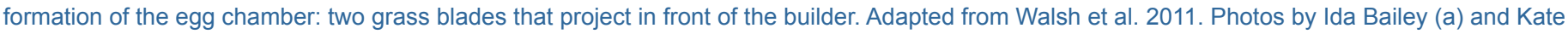
Morgan (b) and (c).
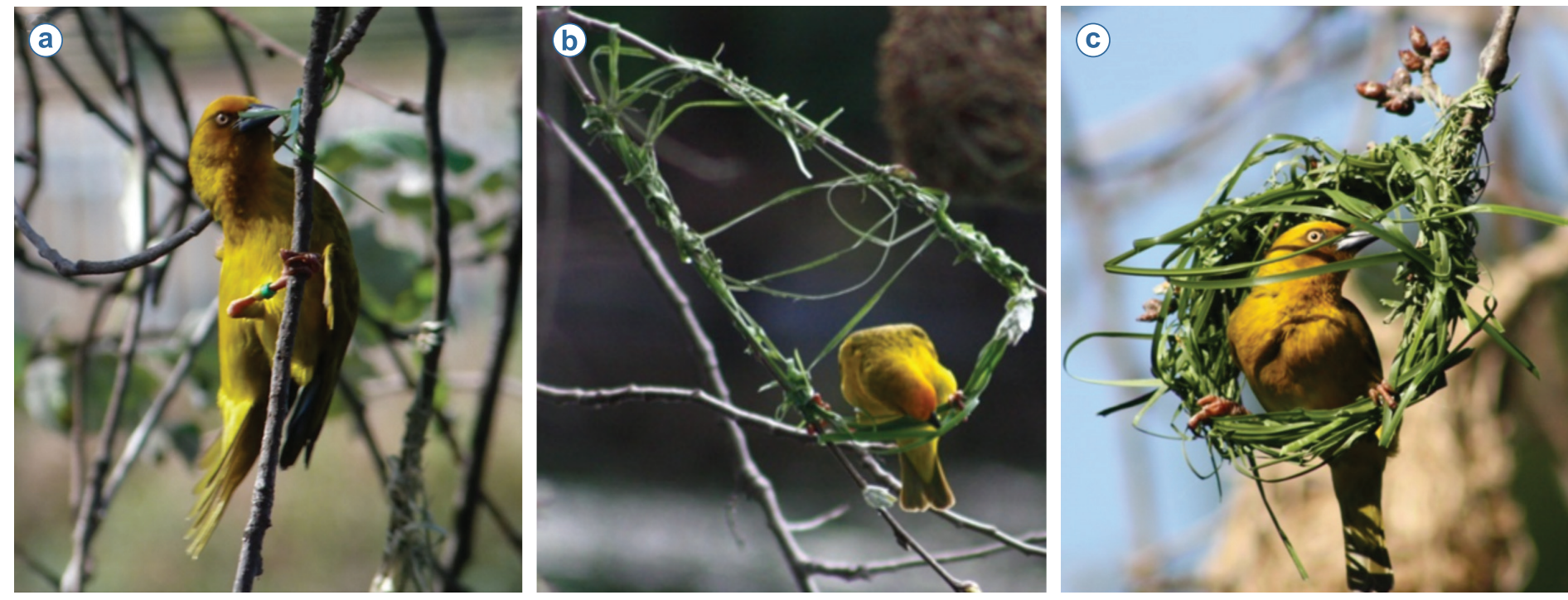
resemblance to closed-end vocal learning in some songbirds with acquisition of variation in the behaviour limited to a sensitive period (Beecher \& Brenowitz, 2005). Further work is required to examine this possibility.

Taken together, these observational data show that the nests built by the same male can vary. They do not, however, necessarily provide evidence for learning. Observational and experimental data from the field on nest-site selection, however, offer more compelling support that birds do use their own experience when making nest-building decisions.

\section{Nest-Site Selection}

One of the decisions a builder needs to make is where to build. A variety of evidence shows that this decision depends on a bird's previous breeding experience (Table 2, Sections 2-7; Lima, 2009). For example, long-term mark and recapture surveys on populations of breeding birds indicate that birds that have an unsuccessful breeding attempt are more likely to build their next nest in a new location (e.g., Northern flickers Colaptes auratus; Doligez, Danchin, Clobert, \& Gustafsson, 1999; collared flycatchers Ficedula albicollis; Dow \& Fredga, 1983; goldeneyes Bucephala clangula; Fisher \& Wiebe, 2006; Table 2, Section 2). Builders might also change the kind of location in which they build. Stonechats Saxicola rubicola, for instance, were more likely to nest in a different vegetation type after suffering nest predation (Greig-Smith, 1982; Table 2, Section 2), whereas Siberian jays Perisoreus infaustus chose to build their next nest in lower, denser vegetation after losing their nest to predation (Eggers, Griesser, Nystrand, \& Ekman, 2006; Table 2, Section 3). Egg removal experiments confirm that breeding experience influences an individual's subsequent nest-site selection: for example, 'unsuccessful' orangebreasted sunbirds Anthobaphes violacea dispersed twice as far between nesting attempts as those that fledged chicks (Grégoire \& Cherry, 2007; Table 2, Section 2). Similarly, between-year breeding-site fidelity was stronger in American robins and brown thrashers Taxostoma rufum that had not experienced simulated nest predation (Haas, 1998; Table 2, Section 2).

In addition to avoiding a previously unsuccessful nest site, birds can also learn to return to a site in which they have raised young successfully (Table 2, Section 2). Mountain bluebirds Sialia currucoides, for example, chose to nest in one of two nestbox types (painted and unpainted) if they had previously fledged chicks from that box type (Herlugson, 1981). Similarly, cliff-nesting kittiwakes Rissa tridactyla will return to nest on cliffs on which they have bred successfully (Danchin, Boulinier, \& Massot, 1998; Suryan \& Irons, 2001) and spotted antbirds Hylophylax naevioides may reuse extant nests from which they have produced young (Styrsky, Brawn, \& Robinson, 2005). These data show that birds can assess and modify their building strategies, in ecological time, in response to environmental variables and outcomes that are associated with nesting success.

There are also observational data to suggest that birds can learn to associate nest success and predation risk (Table 2, Section 3). Between-year breeding-territory fidelity of nesting red-backed shrikes Lanius collurio, for example, changed in relation to the spatial distribution of corvid nest predators (Roos \& Pärt, 2004). Similarly, some pairs of ovenbirds Seiurus aurocapilla in northwestern Pennsylvania will nest in atypical breeding habitat (occupying the forest edges) to lower the risk of losing their eggs and chicks to chipmunks, a nest predator (Morton, 2005).

Whether or not birds modify their nest-building decisions in response to individual predator species has not been explicitly tested (but see Chen, Liu, Yan, \& An, 2011; Table 2, Section 3). There are observational data to show, however, that at least some birds can discriminate between different sources of nest failure: pinyon jays Gymnorhinus cyanocephalus, for example, rebuild in cooler (less exposed) nest sites after nest depredation but will rebuild in warmer (more exposed) sites when a nest fails due to heavy snowfall (Marzluff, 1988; Table 2, Section 3). These data suggest that these decisions are amenable to experimental manipulations of predator presentations (e.g., Hakkarainen, Ilmonen, Koivunen, \& Korpimäki, 2001; Peluc, Sillet, Rotenberry, \& Ghalambor, 2008; Table 2, Section 3).

A bird might also respond to nest predation by modifying the structure of its nest (Table 2, Section 4). For example, house wrens Troglodytes aedon appear to change the structure of their nest in response to an increase in perceived threat exposure: when building in a nestbox with a large (versus a small) entrance hole, these birds construct a far taller stick wall between their nest cup and the entrance hole, which in turn makes access, at least by human hands, more difficult (Stanback et al., 2013). Rather than using sticks, cavitynesting rock wrens Salpinctes obsoletus vary the number of stones they place around the cavity entrance depending on the size of the entrance (Merola, 1995; Smith, 1904; Warning \& Benedict, 2015; Figure 2). This structural modification of rock wrens' nesting environment may itself reduce predator access, but it also appears to amplify the sound of a simulated predator approach, potentially aiding in predator detection (Warning \& Benedict, 2015). Ground nesting black larks Melanocorypha yeltoniensis also seem to build an anti-predator defense for their nest: artificial nests not surrounded by the typical dung 'pavement' of faecal deposits collected from nearby domestic livestock were more likely to 
Figure 2. Three different images depicting variability in facultative rock wren Salpinctes obsoletus nest augmentation-the collection and allocation of stones around the nest cavity entrance. Number of stones placed in each nest: (a) 216; (b) 223; and (c) 602 . Photos by Nat Warning
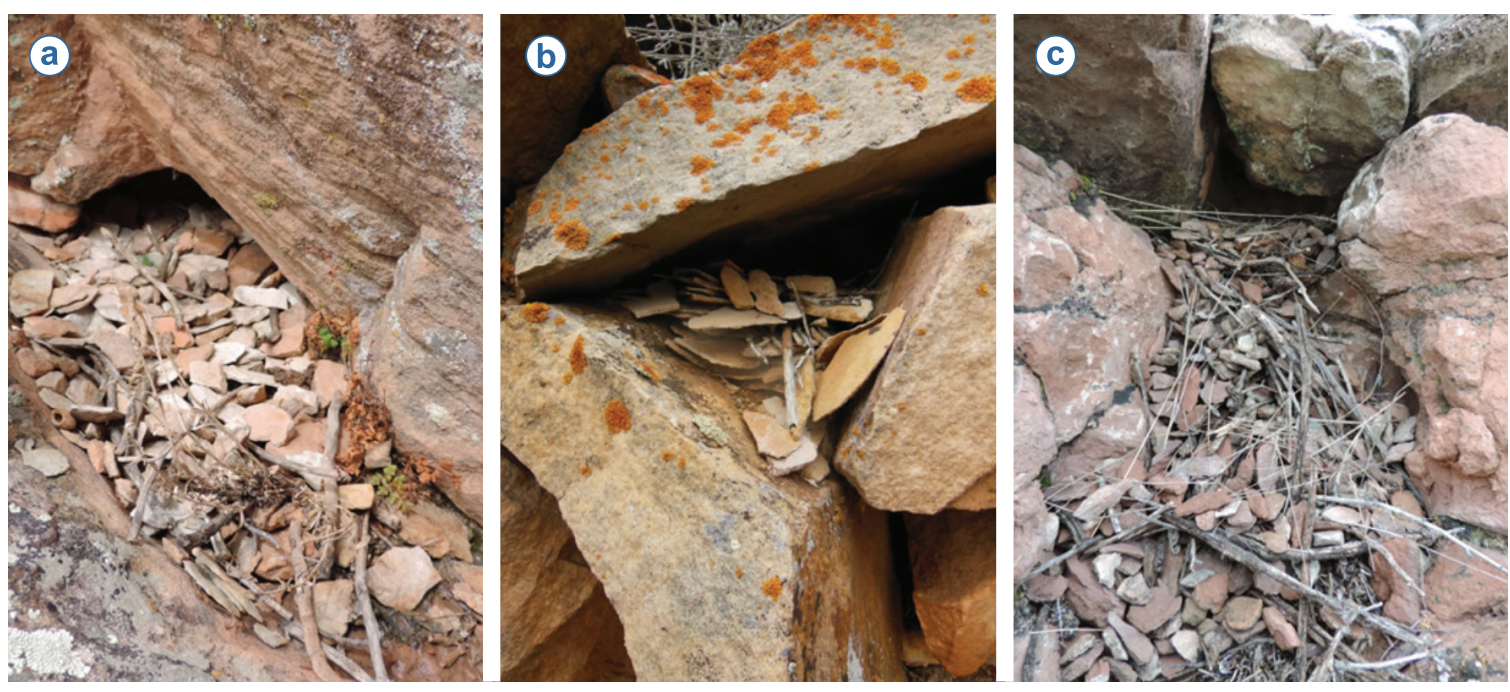

be trampled by cows than were those surrounded by a dung pavement (Moiseev, 1980; Fijen et al., 2015). Whether or not birds facultatively change the structure of the nest itself in response to such environmental variables is not yet clear.

\section{Social Learning and Nest-Site Selection}

Although it has rarely been tested, birds may learn about nest building from watching the choices of other individuals, that is, social learning (Heyes, 1994). For example, observations of nest-site selection by yellow wagtails Motacilla flava (Schiermann, 1939) and redheads Aythya Americana (Hochbaum, 1955) suggested, at least to these authors, that the appearance of new nesting 'traditions' (building in shrubs or on dry land, respectively) were the result of these birds learning from others' nest-building decisions (Table 1, Section 2).

Indeed, kittiwakes Rissa tridactyla (Figure 3) appear to favour information about the relative success or failure of neighbours' nesting attempts when choosing where to build their nest over their own experience: those birds that experienced simulated nest predation (egg removal) tended to return to the same nesting territory if their conspecific neighbours had raised young successfully (Boulinier, McCoy, Yoccoz, Gasparini, \& Tveraa, 2008; Table 2, Section 5). Prothonotary warblers Protonotaria citrea that lose their nest to predation also have stronger site fidelity when their neighbours were successful nesters than when their neighbours were not (Hoover, 2003). Some species take information from their neighbours very seriously indeed: unsuccessful nesting piping plovers Charadrius melodus melodus with unsuccessful neighbours built their next nest more than 34 times further away than did those plovers with neighbours that raised multiple offspring (Rioux, AmiraultLanglais, \& Shaffer, 2011).
Migratory pied Ficedula hypoleuca and collared flycatchers $F$. albicollis pay attention not only to the nestbox type used by heterospecific tit species, but also to the relative success of the tits, and were less likely to copy the tits' apparent nestbox choice (by not moving into a nestbox assigned the same arbitrary, geometric symbol) if the pair of tits had laid a small clutch (Seppänen \& Forsman, 2007; Seppänen, Forsman, Mönkkönen, Krams, \& Salmi, 2011; Table 2, Section 6). It seems that the flycatchers can assess the nesting success of the tits based on some assessment of the number or size of eggs/chicks in the tit nestbox. It is not yet, however, clear by which mechanism the flycatchers 'count' the eggs/chicks they can see when they visit and peek into tit nestboxes (Forsman \& Thomson, 2008). As an aside, the nesting tits appear to attempt to occlude the peeking flycatchers' view of their young: these birds, which typically cover their eggs with nest material (Haftorn \& Slagsvold, 1995), bring more material to cover experimentally exposed eggs in response to a flycatcher call than that of a noncompeting heterospecific (Loukola, Laaksonen, Seppänen, \& Forsman, 2014; Table 2, Section 7).

Birds can, then, use different kinds of interspecific information to estimate nest-site quality when choosing where to locate their own nest. Whether or not birds use social information in other aspects of nest building is still to be addressed.

\section{Social Learning and Building}

There are a number of features of nest building that might be learned from conspecifics such as appropriate materials, effective handling techniques, and the structure to be achieved. And we might expect to see evidence of the influence of building behaviours (e.g., material choice) 


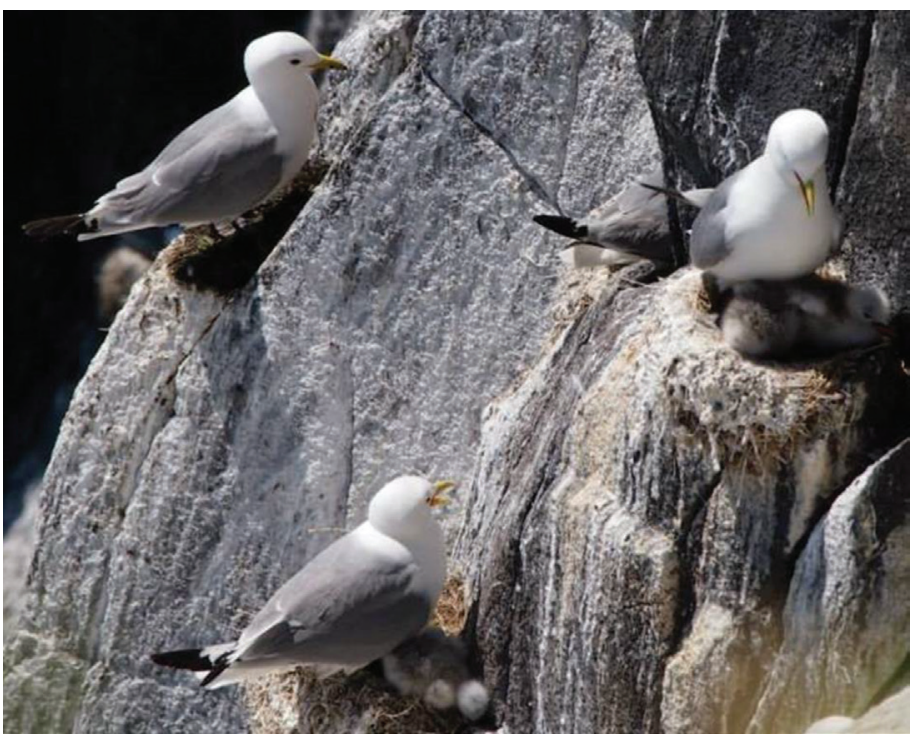

Figure 3. Kittiwakes Rissa tridactyla nesting on the side of a cliff. When a breeding attempt is not successful (top left individual), these birds use intraspecific social information (the relative success or failure of breeding neighbours) to decide where to build their next nest.

Photo by Shoko Sugasawa.

of more experienced and familiar individuals, particularly on the decisions of first-time builders. There is tantalizing evidence that at least some birds appear to "follow the fashion" of others' material choice: over a 10 -year period, Baltimore orioles Icterus galbula provided with both natural (plant) and unnatural (coloured yarn) nest materials increasingly selected pieces of coloured yarn with which to build their nests and the material preferences of all orioles converged to choosing only white yarn, apparently following the example set by a conspecific who would build with nothing else (Williams, 1934; Table 2, Section 8). It is not clear, however, whether first-time builders were more likely to incorporate the coloured yarn than were other birds or whether the birds that chose the white yarn were more likely to have hatched into a nest containing white yarn. The incorporation of coloured yarn into nests by neighbouring kingbirds Tyrannus spp., American robins, and cedar waxwings Bombycilla cedrorum beginning in the same year the orioles' exclusively chose to use white material tells us little about why these birds chose this material but suggests that offering coloured yarn may prove a useful experimental manipulation with which to examine both interspecific as well as intraspecific transmission of material choices.

Differences in aromatic plant species composition in blue tit nests across two distinct, but environmentally similar, study plots also suggest a role for social transmission for material choice (Mennerat, Perret, \& Lambrechts, 2009;
Table 2, Section 8). Aside from these anecdotal reports, however, there is, as yet, no experimental evidence that birds learn how to build, which materials to use, or what structure they should build from observing others.

\section{Nest Design}

The question of how a bird knows what structure to build and whether asocial experience might shape that product remains equally untested, at least in the wild (but see below for recent laboratory data). But as there is evidence that variation in nest structure or materials can lead to variation in reproductive success, it would appear that there is potential for builders to learn how to change the structure of their next nest. Black lark chicks, for example, reared in nests where females had incorporated a greater amount of surrounding livestock dung had higher tarsus growth rates than did chicks reared in nests surrounded by less dung (Fijen et al., 2015). Similarly, removal or addition of feathers from nests of tree swallows Tachycineta bicolor either decreased or increased chick growth rate, respectively (Winkler, 1993; Dawson, O’Brien, \& Mlynowski, 2011).

If material choice enhances a bird's reproductive success, then that bird might change the construction of its next nest by, for example, altering the number of feathers (in the case of the swallows) or quantity of faecal matter (in the case of the larks) based on prior breeding success or failure. They might also learn to select or avoid material(s) based on their structural suitability: biomechanical analysis shows that female blackbirds Turdus merula consistently allocate stronger, thicker, and more rigid material elements differentially within the nest structure, although it is not clear that they have learned to do this (Biddle, Deeming, \& Goodman, 2015).

\section{Learning in Nest-Building Birds: Evidence from the Laboratory}

\section{Model Species}

Experimental investigation into the cognition of nest building has been focussed on nest building in male zebra finches. Although more widely recognized for their pivotal role in investigations related to birdsong (e.g., neurological, developmental, functional), these birds are a useful laboratory model species for investigating a range of behaviours and cognition (Healy, Haggis, \& Clayton, 2010) for several key reasons: zebra finches (a) readily breed and build nests under laboratory conditions with a variety of materials (Figure 4); (b) have short (90 day) generation times; and (c) immediately recommence nest building when their young have fledged. 
Figure 4. A series of photographs showing a pair of zebra finches Taeniopygia guttata (a) and a variety of the different materials with which the male will build a nest (b-d), such as orange (e) or pink (g) twine or non-dyed stiff string (f) under laboratory conditions. Photos by Eira Ihalainen $(\mathrm{a}-\mathrm{e}, \mathrm{g})$ and Alexis Breen (f).
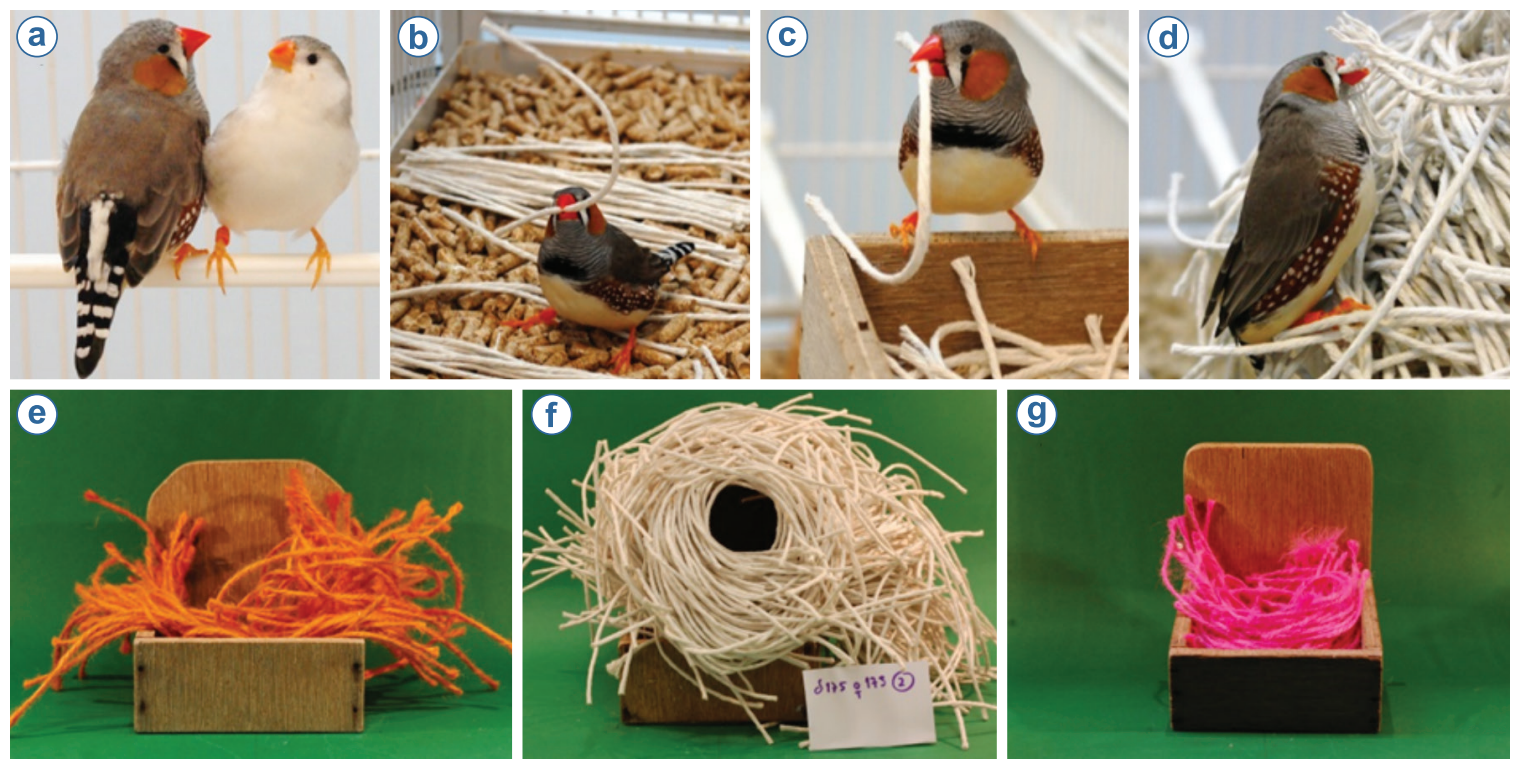

\section{Material Choice}

Although it seems plausible that birds may benefit from choosing certain materials for building their nest, this assumes that birds 'know' what constitutes a 'good' material choice. But it does appear that zebra finches can, at least, assess the quality of building materials (whether by breeding experience and/or sensitivity to material properties) and then respond to them selectively (Table 3, Sections 1-2). For example, males that built a nest using material of a colour they did not prefer but from which they raised chicks, subsequently preferred that colour of material for building their next nest, while males that were unsuccessful in raising chicks in a nest built with material of the preferred colour did not switch preference for material colour (Muth \& Healy, 2011; Table 3, Section 1). Why this latter group of birds did not switch their preference is not yet clear. But it does appear that there is complexity and subtlety to what birds learn from their own building experience. The cause of initial colour preferences requires further investigation, although birds do not appear to prefer the colour of nest material from which they fledged (Muth \& Healy, 2012; Muth, Steele, \& Healy, 2013; Sargent, 1965; Table 3, Section 2).

Like animal tool users (e.g., Manrique, Sabbatini, Call, \& Visalberghi, 2011; Sanz, Call, \& Morgan, 2009; St Clair \& Rutz, 2013), male zebra finches will also attend to the structural properties of nest materials. For example, finches given wire-mesh nestboxes with either a small or a large entrance selected material of the appropriate length for their nestbox (long material for a large entrance hole and short for a small one) when both of these materials were made available
(Muth \& Healy, 2014; Table 3, Section 2). Over the course of handling the material, however, the males building in the nestboxes with a small entrance hole modified the way in which they held the material such that they could build with both the short and long material. The birds' initial choices would suggest that they had assessed which was the appropriate material for the size of their nestbox entrance, but that they could learn to use a different motor technique in order to make more effective use of the available material. This change in material choice as the birds built suggests at least two things: (a) that building decisions can be updated through the building process; and (b) that the points at which decisions change or their causes may not be apparent from examination of the resulting structure. Detailed observations and/or manipulations of building will be required to investigate decision making and any contribution made to building by cognition.

That male zebra finches learn about the structural properties of nest materials is also supported by evidence that, after building a nest with long $(15 \mathrm{~cm})$, flexible string, birds preferred to build a second nest with $15 \mathrm{~cm}$ stiff string (Bailey, Morgan, Bertin, Meddle, \& Healy, 2014; Table 3, Section 2). This preference appears to be due to the birds' having learned that the flexible string was costly: males that built a nest with flexible string required twice as many pieces as did males that built with the stiff string.

\section{Neural Architecture}

Although there is a considerable literature on the neural and hormonal underpinnings of reproduction in birds, the 
nest-building component of this process has received little attention (Hall, Bertin, Bailey, Meddle, \& Healy, 2014; Kingsbury, Jan, Klatt, \& Goodson, 2015; Klatt \& Goodson, 2013). Given the interest in developing avian models for the study of cognitive neuroscience (e.g., Clayton \& Emery, 2015), nest building might be such a system. For example, immediate early gene activity shows that a number of neural circuits, such as the anterior motor pathway (involved in motor learning and sequencing), the social behaviour network (involved in a suit of social and reproductive behaviour in vertebrates), and the mesotocinergic, vasotocinergic, and dopaminergic reward system (involved in the motivation, and production of, social and reproductive behaviour), are all active when birds build nests (Hall et al., 2014; Hall, Healy, \& Meddle, 2015).

Examination of the primate brain suggest that at least some of the neural processes involved in nest building may extend to construction behaviours more generally. Indeed, functional brain imaging techniques (Obayashi et al., 2001) have revealed that tool use by Japanese macaques Macaca fuscata produces similar activation patterns in the anterior motor pathway to those observed in birds building nests (Hall et al., 2014). The nature of the apparent similarity in the neurobiological processes underlying tool use and nest building, however, is not yet clear.

Given the phenotypic similarity between nest building and tool use in birds, it seems plausible that the neural underpinning of the two behaviours might also share common features. This possibility is supported by evidence that (a) tool users have a more foliated cerebellum (a brain region involved in motor control) than do non-tool users (Barton, 2012; Iwaniuk, Lefebvre, \& Wylie, 2009), and that (b) cerebellar foliation increases with nest structure complexity (no nest $<$ platform nest $<$ cup nest; Hall, Street, \& Healy, 2013). These data are just the beginning for what promises to be a productive brain-behaviour model.

\section{Nest Building as a Model in Comparative Cognition}

A handful of models for comparative cognition have been chosen because the species in question has a purported adaptive specialization for one cognitive ability or another (e.g., spatial memory in food-storing species; Biegler, McGregor, Krebs, \& Healy, 2001; transitive inference in species that differ in social structure; Bond, Kamil, \& Balda, 2003; timing in nectarivorous animals, e.g., bees and hummingbirds; Skorupski \& Chittka, 2006; Henderson, Hurly, Bateson, \& Healy, 2006; respectively; categorisation in songbirds; Sturdy, 2007). With the increasing interest in understanding physical cognition, particularly in birds (Guillette \& Healy, 2015; Shettleworth, 2009), and the development and neural basis of cognition (Clayton \& Emery, 2015), nest building in birds provides a range of features that may make it a useful comparative 'model' system for investigating brainbehaviour relationships. These features include: (a) variability within and across species (in nest structure, materials used, building technique, identity of builder; Hansell, 2000); (b) evidence of the role that learning plays in multiple aspects of nest building (Tables 2 and 3); and (c) extensive, in-depth study of avian neuroanatomy (Ziegler \& Marler, 2012). Importantly, nest building is also amenable to experimental manipulation, both in the laboratory and in the field.

Model system or not, for the comparative cognition enthusiast, it is the second point that offers the most promise for future work. For, although there is much known about some aspects of avian nest building (Healy, Morgan, \& Bailey, 2015), there is still an awful lot to learn. For example, do imprinting and/or other kinds of early-life experience play a role, and if so, on what components of building (e.g., motor skills, material choices, what structure to build)? To what extent does social learning play a role? Do birds continuously update their nest-building skills and decisions? Does skill at nest building correlate with ability to solve so-called physical cognition tasks? Are there sex differences in any of the relevant abilities, and to what extent is there interspecific variation? There is much scope for comparison to be made.

\section{References}

Antczak, M., Hromada, M., Czechowski, P., Tabor, J., Zablocki, P., Grzybek, J., \& Tryjanowski, P. (2010). A new material for old solutionsthe case of plastic string used in Great Grey Shrike nests. Acta Ethologica, 13(2), 87-91. doi:10.1007/s10211-010-0077-2

Bailey, I. E., Backes, A., Walsh, P. T., Morgan, K. V., Meddle, S. L., \& Healy, S. D. (2015). Image analysis of weaverbird nests reveals signature weave textures. Royal Society Open Science, 2(6), 150074. doi:10.1098/rsos.150074

Bailey, I. E., Morgan, K. V., Bertin, M., Meddle, S. L., \& Healy, S. D. (2014). Physical cognition: Birds learn the structural efficacy of nest material. Proceedings of the Royal Society B, 281(1784), 20133225. doi:10.1098/rspb.2013.3225 
Barton, R. A. (2012). Embodied cognitive evolution and the cerebellum. Philosophical Transactions of the Royal Society B, 367(1599), 2097-2107. doi:10.1098/rstb.2012.0112

Bateson, P. P. G. (1966). The characteristics and context of imprinting. Biological Reviews, 41, 177-220. doi:10.1111/j.1469-185X.1966.tb01489.x

Bateson, P. P. G. (2015). Thirty years of collaboration with Gabriel Horn. Neuroscience \& Biobehavioral Reviews, 50, 4-11. doi:10.1016/j.neubiorev.2014.09.019

Beecher, M. D., \& Brenowitz, E. A. (2005). Functional aspects of song learning in songbirds. Trends in Ecology \& Evolution, 20(3), 143-149. doi:10.1016/j.tree.2005.01.004

Biddle, L. E., Deeming, D. C., \& Goodman, A. M. (2015). Morphology and biomechanics of the nests of the Common Blackbird Turdus merula. Bird Study, 62(1), 87-95. doi:10.1080/00063657.2014.988119

Biegler, R., McGregor, A., Krebs, J. R., \& Healy, S. D. (2001). A larger hippocampus is associated with longer-lasting spatial memory. Proceedings of the National Academy, USA, 98(12), 6941-6944. doi:10.1073/pnas.121034798

Bluff, L. A., Weir, A. A., Rutz, C., Wimpenny, J. H., \& Kacelnik, A. (2007). Tool-related cognition in New Caledonian Crows. Comparative Cognition \& Behavior Reviews, 1, 1-25. doi:10.3819/ccbr.2008.20001

Boake, C. R. B. (1989). Repeatability: Its role in evolutionary studies of mating behavior. Evolutionary Ecology, 3(2), 173-182. doi:10.1007/BF02270919

Bond, A. B., Kamil, A. C., \& Balda, R. P. (2003). Social complexity and transitive inference in corvids. Animal Behaviour, 65(3), 479-487. doi:10.1006/anbe.2003.2101

Boulinier, T., McCoy, K. D., Yoccoz, N. G., Gasparini, J., \& Tveraa, T. (2008). Public information affects breeding dispersal in a colonial bird: Kittiwakes cue on neighbours. Biology Letters, 4(5), 538-540. doi:10.1098/rsbl.2008.0291
Chen, J. N., Liu, N. F., Yan, C., \& An, B. (2011). Plasticity in nest site selection of Black Redstart (Phoenicurus ochruros): A response to human disturbance. Journal of Ornithology, 152(3), 603-608. doi:10.1007/s10336-010-0622-9

Clayton, N. S., \& Emery, N. J. (2015). Avian models for human cognitive neuroscience: A proposal. Neuron, 86(6), 1330-1342. doi:10.1016/j.neuron.2015.04.024

Collias, E. C., \& Collias, N. E. (1964). The development of nest-building behavior in a weaverbird. The Auk, 81(1), 42-52.

Collias, N. E., \& Collias, E. C. (1984). Nest Building and Bird Behavior. Princeton, NJ: Princeton University Press.

Danchin, E., Boulinier, T., \& Massot, M. (1998). Conspecific reproductive success and breeding habitat selection: Implications for the study of coloniality. Ecology, 79(7), 2415-2428. doi:10.1890/0012-9658(1998)079[2415 :CRSABH]2.0.CO;2

Dawson, R. D., O’Brien, E. L., \& Mlynowski, T. J. (2011). The price of insulation: Costs and benefits of feather delivery to nests for male tree swallows Tachycineta bicolor. Journal of Avian Biology, 42(2), 93-102. doi:10.1111/j.1600-048X.2010.05208.x

Deeming, D. C., \& Ferguson, M. (1989). In the heat of the nest. New Scientist, 121(1657), 33-38.

Deeming, D. C., \& Reynolds, S. J. (2015). Nests, eggs and incubation: New ideas about avian reproduction. Oxford, UK: Oxford University Press.

Doligez, B., Danchin, E., Clobert, J., \& Gustafsson, L. (1999). The use of conspecifc reproductive success for breeding habitat selection in a non-colonial, hole-nesting species, the collared flycatcher. Journal of Animal Ecology, 68(33), 1193-1206. doi:doi:10.1676/13-108.1

Domjan, M. (2014). The Principles of Learning and Behavior. Stamford, CT: Cengage Learning. 
Dow, H., \& Fredga, S. (1983). Breeding and natal dispersal of the goldeneye, Bucephala clangula. Journal of Animal Ecology, 52(3), 681-695.

Eggers, S., Griesser, M., Nystrand, M., \& Ekman, J. (2006). Predation risk induces changes in nestsite selection and clutch size in the Siberian jay. Proceedings of the Royal Society B, 273(1587), 701-706. doi:10.1098/rspb.2005.3373

Fijen, T. P. M., Kamp, J., Lameris, T. K., Pulikova, G., Urazaliev, R., Kleijn, D., \& Donald, P. F. (2015). Functions of extensive animal dung "pavements" around the nests of the Black Lark (Melanocorypha yeltoniensis). The Auk, 132(4), 878-892. doi:10.1642/AUK-15-38.1

Fisher, R. J., \& Wiebe, K. L. (2006). Breeding dispersal of Northern Flickers Colaptes auratus in relation to natural nest predation and experimentally increased perception of predation risk. Ibis, 148(4), 772-781. doi:10.1111/j.1474-919X.2006.00582.x

Forsman, J. T., \& Thomson, R. L. (2008). Evidence of information collection from heterospecifics in cavity-nesting birds. Ibis, 150(2), 409-412. doi:10.1111/j.1474-919X.2007.00773.X

Grégoire, A., \& Cherry, M. I. (2007). Nesting success and within-season breeding dispersal in the Orange-breasted Sunbird Anthobaphes violacea. Ostrich, 78(3), 633-636. doi:10.2989/OSTRICH.2007.78.3.10.321

Greig-Smith, P. W. (1982). Dispersal between nest-sites by Stonechats Saxicola torquata in relation to previous breeding succes. Ornis Scandinavica, 13(3), 232-238. doi: $10.2307 / 3676304$

Guillette, L. M., \& Healy, S. D. (2015). Nest building, the forgotten behaviour. Current Opinion in Behavioural Sciences, 6, 90-96. doi:10.1016/j.cobeha.2015.10.009

Haas, C. (1998). Effects of prior nesting success on site fidelity and breeding dispersal: An experimental approach. The Auk, 115(4), 929-936.
Haftorn, S., \& Slagsvold, T. (1995). Egg covering in birds: Description of the behaviour in tits (Parus spp.) and a test of hypotheses of its function. Fauna Norvegica, Series C Cinclus, 18(2), 85-106.

Hakkarainen, H., Ilmonen, P., Koivunen, V., \& Korpimäki, E. (2001). Experimental increase of predation risk induces breeding dispersal of Tengmalm's owl. Oecologia, 126(3), 355-359. doi:10.1007/s004420000525

Hall, Z. J., Bertin, M., Bailey, I. E., Meddle, S. L., \& Healy, S. D. (2014). Neural correlates of nesting behavior in zebra finches (Taeniopygia guttata). Behavioural Brain Research, 264, 26-33. doi:10.1016/j.bbr.2014.01.043

Hall, Z. J., Healy, S. D., \& Meddle, S. L. (2015). A role for nonapeptides and dopamine in nest-building behaviour. Journal of Neuroendocrinology, 27(2), 158-165. doi:10.1111/jne.12250

Hall, Z. J., Street, S. E., \& Healy, S. D. (2013). The evolution of cerebellum structure correlates with nest complexity. Biology Letters, 9(6), 20130687. doi:10.1098/rsbl.2013.0687

Hansell, M. (1984). Animal architecture and building behaviour. London: Longman.

Hansell, M. (2000). Bird nests and construction behaviour. Cambridge, UK: Cambridge University Press.

Hansell, M., \& Ruxton, G. D. (2008). Setting tool use within the context of animal construction behaviour. Trends in Ecology and Evolution, 23(2), 73-78. doi:10.1016/j.tree.2007.10.006

Healy, S. D., Haggis, O., \& Clayton, N. S. (2010). Zebra Finches and cognition. Emu, 110(3), 242-250. doi:10.1071/MU10004

Healy, S. D., Morgan, K. V., \& Bailey, I. E. (2015). Nest construction behaviour. In C. D. Deeming \& J. S. Reynolds (Eds.), Nests, eggs and incubation: New ideas about avian reproduction, 16-28. Oxford, UK: Oxford University Press. 
Henderson, J., Hurly, A. T., Bateson, M., \& Healy, S. D. (2006). Timing in free-living rufous hummingbirds, Selasphorus rufus. Current Biology, 16, 512-515. doi:10.1016/j.cub.2006.01.054

Herlugson, C. J. (1981). Nest site selection in Mountain Bluebirds. Condor, 83(3), 252-255.

Heyes, C. M. (1994). Social learning in animals: Categories and mechanisms. Biological Reviews of the Cambridge Philosophical Society, 69, 207-231. doi:10.1111/j.1469-185X.1994.tb01506.x

Hinde, R. A., \& Warren, R. P. (1959). The effect of nest building on later reproductive behaviour in domesticated canaries. Animal Behaviour, 7(1-2), 35-41. doi:10.1016/0003-3472(59)90028-4

Hochbaum, H. A. (1955). Travels and traditions of waterfowl. Minneapolis, MN: Univ. of Minnesota Press.

Hoover, J. P. (2003). Decision rules for site fidelity in a migratory bird, the Prothonotary Warbler. Ecology, 84(2), 416-430. doi:10.1890/0012-9658(2003)084[0416 :DRFSFI]2.0.CO;2

Iwaniuk, A. N., Lefebvre, L., \& Wylie, D. R. (2009). The comparative approach and brain-behaviour relationships: A tool for understanding tool use. Canadian Journal of Experimental Psychology, 63(2), 150-159. doi:10.1037/a0015678

Kingsbury, M. A., Jan, N., Klatt, J. D., \& Goodson, J. L. (2015). Nesting behavior is associated with VIP expression and VIP-Fos colocalization in a networkwide manner. Hormones and Behavior, 69, 68-81. doi:10.1016/j.yhbeh.2014.12.010

Klatt, J. D., \& Goodson, J. L. (2013). Sex-specific activity and function of hypothalamic nonapeptide neurons during nest-building in zebra finches. Hormones and Behavior, 64(5), 818-824. doi:10.1016/j.yhbeh.2013.10.001

Lessells, C. M., \& Boag, P. T. (1987). Unrepeatable repeatabilities: A common mistake. Auk, 104, 116-121. doi: $10.2307 / 4087240$
Lima, S. L. (2009). Predators and the breeding bird: Behavioral and reproductive flexibility under the risk of predation. Biological Reviews, 84(3), 485-513. doi:10.1111/j.1469-185X.2009.00085.X

Loukola, O. J., Laaksonen, T., Seppänen, J. T., \& Forsman, J. T. (2014). Active hiding of social information from information-parasites. BMC Evolutionary Biology, 14(1), 32. doi:10.1186/1471-2148-14-32

Manrique, H. M., Sabbatini, G., Call, J., \& Visalberghi, E. (2011). Tool choice on the basis of rigidity in capuchin monkeys. Animal Cognition, 14(6), 775-786. doi:10.1007/s10071-011-0410-9

Marzluff, J. M. (1988). Do pinyon jays alter nest placement based on prior experience? Animal Behaviour, 36(1), 1-10. doi:10.1016/S0003-3472(88)80244-6

Mennerat, A., Perret, P., \& Lambrechts, M. M. (2009). Local individual preferences for nest materials in a passerine bird. PLOS ONE, 4(4), 2-7. doi:10.1371/journal.pone.0005104

Merola, M. (1995). Observations on the nesting and breeding behavior of the Rock Wren. Condor, 97(2), 585-587. doi:10.2307/1369046

Moiseev, A. (1980). The breeding biology of the Black Lark in Central and Northern Kazakhstan. In A. A. Kovshar (Ed.), Biology of the Birds of Naurzum State Protected Area, 1st ed., 120-126. Nauka, Alma-Ata, Kazakhstan.

Morton, E. S. (2005). Predation and variation in breeding habitat use in the Ovenbird, with special reference to breeding habitat selection in northwestern Pennsylvania. The Wilson Bulletin, 117(4), 327-335. doi:10.1676/04-135.1

Muth, F., \& Healy, S. D. (2011). The role of adult experience in nest building in the zebra finch, Taeniopygia guttata. Animal Behaviour, 82(2), 185-189. doi:10.1016/j.anbehav.2011.04.021

Muth, F., \& Healy, S. D. (2012). Zebra finches build nests that do not resemble their natal nest. Avian Biology Research, 5(4), 218-226. doi:10.3184/175815512X13531725598475 
Muth, F., \& Healy, S. D. (2014). Zebra finches select nest material appropriate for a building task. Animal Behaviour, 90, 237-244. doi:10.1016/j.anbehav.2014.02.008

Muth, F., Steele, M., \& Healy, S. D. (2013). Colour preferences in nest-building zebra finches. Behavioural Processes, 99, 106-111. doi:10.1016/j.beproc.2013.07.002

Nicolakakis, N., \& Lefebvre, L. (2000). Forebrain size and innovation rate in European birds: Feeding, nesting and confounding variables. Behaviour, 137(11), $1415-1429$.

Obayashi, S., Suhara, T., Kawabe, K., Okauchi, T., Maeda, J., Akine, Y., Onoe, Hirotaka, \& Iriki, A. (2001). Functional brain mapping of monkey tool use. NeuroImage, 14(4), 853-861. doi:10.1006/nimg.2001.0878

Peluc, S. I., Sillett, T. S., Rotenberry, J. T., \& Ghalambor, C. K. (2008). Adaptive phenotypic plasticity in an island songbird exposed to a novel predation risk. Behavioral Ecology, 19(4), 830-835. doi:10.1093/beheco/arn033

Raby, C. R., \& Clayton, N. S. (2009). Prospective cognition in animals. Behavioural Processes, 80(3), 314-24. doi:10.1016/j.beproc.2008.12.005

Rioux, S., Amirault-Langlais, D. L., \& Shaffer, F. (2011). Piping Plovers make decisions regarding dispersal based on personal and public information in a variable coastal ecosystem. Journal of Field Ornithology, 82(1), 32-43. doi:10.1111/j.1557-9263.2010.00305.x

Roos, S., \& Pärt, T. (2004). Nest predators affect spatial dynamics of breeding red-backed shrikes (Lanius collurio). Journal of Animal Ecology, 73(1), 117-127. doi:10.1111/j.1365-2656.2004.00786.x

Sanz, C., Call, J., \& Morgan, D. (2009). Design complexity in termite-fishing tools of chimpanzees (Pan troglodytes). Biology Letters, 5(3), 293-296. doi:10.1098/rsb1.2008.0786

Sargent, T. D. (1965). The role of experience in the nest building of the Zebra Finch. The Auk, 48-61.
Schiermann, G. (1939). "Stammesgenossenschaften" bei Vögeln. Ornithologische Monatsbererichte, 47, 1-3.

Scott, W. E. D. (1902). Instinct in song birds, method of breeding in hand-reared robins (Merula migratoria). Science, 16(393), 70-71. doi:10.1126/science.16.393.70

Scott, W. E. D. (1904). The inheritance of song in passerine birds. Further observations on the development of song and nest-building in handreared Rose-breasted Grosbeaks, Zamelodia ludoviciana (Linnaeus). Science, 20(504), 282-283. doi:10.1126/science.20.504.282

Seed, A., \& Byrne, R. (2010). Animal tool-use. Current Biology, 20(23), R1032-R1039. doi:10.1016/j.cub.2010.09.042

Seppänen, J. T., \& Forsman, J. T. (2007). Interspecific social learning: Novel preference can be acquired from a competing species. Current Biology, 17(14), 12481252. doi:10.1016/j.cub.2007.06.034

Seppänen, J. T., Forsman, J. T., Mönkkönen, M., Krams, I., \& Salmi, T. (2011). New behavioural trait adopted or rejected by observing heterospecific tutor fitness. Proceedings of the Royal Society B, 278(1712), 17361741. doi:10.1098/rspb.2010.1610

Shettleworth, S. J. (2009). The evolution of comparative cognition: Is the snark still a boojum? Behavioural Processes, 80(3), 210-217. doi:10.1016/j.beproc.2008.09.001

Skorupski, P., \& Chittka, L. (2006). Animal cognition: An insect's sense of time? Current Biology, 16(19), 853-855. doi:10.1016/j.cub.2006.08.069

Smith, P. (1904). Nesting habits of the Rock wren. Condor, $6,109-110$.

St Clair, J. J. H., \& Rutz, C. (2013). New Caledonian crows attend to multiple functional properties of complex tools. Philosophical Transactions of the Royal Society B, 368(1630), 20120415. doi:10.1098/rstb.2012.0415 
Stanback, M. T., Bartholomew, J. E., Bergner, L. M., Cline, E. L., Helms, P. I., McGovern, P. G., ... Roth, J. E. (2013). House wrens alter nest architecture to compensate for cavity vulnerability. The Wilson Journal of Ornithology, 125, 174-178. doi:10.1242/jeb.089763

Sturdy, C. B. (2007). Auditory category perception as a natural cognitive activity in songbirds. Comparative Cognition \& Behavior Reviews. doi:10.3819/ccbr.2008.20006

Styrsky, J. N., Brawn, J. D., \& Robinson, S. K. (2005). Juvenile mortality increases with clutch size in a neotropical bird. Ecology, 86(12), 3238-3244. doi:10.1890/04-1613

Suárez-Rodríguez, M., López-Rull, I., \& Garcia, C. M. (2013). Incorporation of cigarette butts into nests reduces nest ectoparasite load in urban birds: New ingredients for an old recipe? Biology Letters, 9(1), 20120931. doi:10.1098/rsbl.2012.0931

Suryan, R. M., \& Irons, D. B. (2001). Colony and population dynamics of black-legged kittiwakes in a heterogeneous environment. The Auk, 118(3), 636-649.

Verlaine, L. (1934). L'instinct et l'intelligence chez les oiseaux. Recherches Philosoph, 3, 285-305.

Wallace, A. R. (1867). The philosophy of birds' nests. Intellectual Observer, 11, 413-420.
Walsh, P. T., Hansell, M., Borello, W. D., \& Healy, S. D. (2010). Repeatability of nest morphology in African weaver birds. Biology Letters, 6(2), 149-151. doi:10.1098/rsbl.2009.0664

Walsh, P. T., Hansell, M., Borello, W. D., \& Healy, S. D. (2011). Individuality in nest building: Do Southern Masked weaver (Ploceus velatus) males vary in their nest-building behaviour? Behavioural Processes, 88(1), 1-6. doi:10.1016/j.beproc.2011.06.011

Walsh, P. T., Hansell, M., Borello, W. D., \& Healy, S. D. (2013). Are elaborate bird nests built using simple rules? Avian Biology Research, 6(2), 157-162. doi:10.3184/175815513X13629302805186

Warning, N., \& Benedict, L. (2015). Paving the way: Multifunctional nest architecture of the Rock Wren. The Auk, 132(1), 288-299. doi:10.1642/AUK-14-186.1

Williams, H. S. (1934). Nest building-new style. Natural History, 34, 431-446.

Winkler, D. W. (1993). Use and importance of feathers as nest lining in tree swallows (Tachycineta bicolor). The Auk, 110(1), 29-36. doi:10.2307/4088228

Zentall, T. R. (2006). Mental time travel in animals: A challenging question. Behavioural Processes, 72(2), 173-183. doi:10.1016/j.beproc.2006.01.009

Ziegler, H. P., \& Marler, P. (2012). Neuroscience of Birdsong. New York, NY: Cambridge University Press. 